\title{
Using ICT in the Management of Public Open Space as a Commons
}

\author{
Georgios Artopoulos ${ }^{1(\bowtie)}(\mathbb{D})$, Paschalis Arvanitidis $^{2}$ (D), \\ and Sari Suomalainen ${ }^{3}$ (D) \\ 1 The Cyprus Institute, Nicosia, Cyprus \\ g.artopoulos@cyi.ac.cy \\ ${ }^{2}$ University of Thessaly, Volos, Greece \\ parvanit@uth.gr \\ ${ }^{3}$ Häme University of Applied Sciences, Hämeenlinna, Finland \\ sari.suomalainen@hamk. fi
}

\begin{abstract}
The chapter defines public open space as a commons and explores innovative ways for its management and sustainable development through the use of new information and communication technologies. It argues that hybrid conglomerates of space and technological interfaces provide this possibility. Section 2 defines common pool resources and discusses issues of its management, before it moves to identify public open space as a commons and to outline key directives for governance. Section 3 outlines the new ICT and considers practices and technologies that can be used in order to enhance community identity, social interaction and user engagement in the governance of the public open space as a commons. Finally, the last section concludes this chapter with some remarks on the conditions under which the hybrid of a public open space with ICT features could be approached as yet another kind of 'soft' type of common pool resource.
\end{abstract}

Keywords: Public open space $\cdot$ Common pool resource

Spatialised cultural interaction $\cdot$ Open data $\cdot$ User engagement

\section{Introduction}

Public Open Space (POS) is a key element of our cities. It can be defined as outdoor urban spaces of any size, design or physical features, which are readily and freely available to the public for amenity, recreation, and socialisation purposes (Lemonides and Young 1978). POS affords many benefits to urban dwellers, and provides opportunities for relaxation, association and social interaction, which help communities to shape their identity and to strengthen their social fabric (CABE space 2004). Yet, most writers on public space issues acknowledge a general decline in the quality and quantity of POS worldwide, attributing this to the lack of resources and/or vision, to outdated working practices, and to fragmented organisational structures on the part of the local authorities (Carmona and De Magalhaes 2006; Arvanitidis and Nasioka 2017). Along these lines, a number of scholars, policy makers and international 
organizations have placed emphasis on bottom-up approaches, acknowledging (at least implicitly) that POS is, in essence, a common pool resource (CPR) and as such users, and the public in general, together with the local authorities and other stakeholders, should collectively engage in its management, planning and protection (Fraser et al. 2006; Ernstson et al. 2008).

Contemporary approaches to landscape architecture make an argument for inclusive strategies in urban design placing emphasis on the use of event spaces (Shinew et al. 2004). Recent research in psychology of space reveals how event spaces that are incorporated in natural landscapes and ecosystems create vivid experiences and offer the conditions necessary for creative learning and participatory action. Importantly, these spaces should be seen as parts of, and convergent locales within, an extended network of POS. This network is not fixed, like a snapshot of space at a specific point in time, but rather in a process of continuous development and transformation that is associated with the human activities that it hosts and is contextualised in space. New information and communications technologies (ICT) and the development of visualisation techniques expand human experience to enrich interaction with both people and space (De Souza e Silva and Frith 2012).

This chapter acknowledges that most discussions in the field approach the analysis of common resources with economic terms. The chapter expands its scope beyond urban economics in order to engage in the discourse a more diverse approach to considering POS as CPR. It does so by arguing that spatialised (inter)cultural exchanges of views, habits, occupation patterns and everyday activities can be studied as yet another set of performative capacities of the space as CPR (Gidwani and Baviskar 2011) to be facilitated by ICT. ICT can potentially play an important role in activating POS because the latter is characterised as being more uncertain in valuation than exemplar cases of CPR - and therefore more difficult to be measurable or defined by the tools and theories mentioned below. Based on this approach, the chapter defines POS as a commons and explores innovative ways for its management and sustainable development through the use of new ICT. By augmenting the lived experiences of a place, they create a feeling of 'belonging' and 'togetherness' supporting the emergence of common identities (Low et al. 2005) between users. This chapter offers some remarks on the conditions under which the hybrid of a POS with ICT features could be approached as yet another kind of 'soft' type of CPR.

\section{Public Open Space as a Commons}

\subsection{The Common Pool Resources and the Commons}

In economics, CPRs refer to goods that at one and the same time, are not amenable to exclusion, but are subject to rivalry; the first signifying the excessive difficulty or cost in excluding people from their appropriation, and the second that use by some compromises the quality and availability of the resource to other potential users. Due to these attributes CPRs are susceptible to overuse, leading to congestion and engendering the progressive depletion, degradation and eventual destruction of the resource; something Hardin (1968) terms "the tragedy of the commons". 
In the quest to resolve the quandary and avoid the inevitable tragedy, scholars have suggested the idea of promoting the ethics of stewardship among users in an attempt to encourage more moral and altruistic behaviour patterns that would improve prospects of sustainability (Barclay 2004). Others (e.g. Libecap 2009), in line with Hardin (1968), have emphasized the necessity of designating such resources with clearly defined property rights; thus, endowing the putative 'owners' with the incentive and ability to safeguard the future of these resources in their own interests. Two prospective governance regimes have been proposed to achieve this: the first is privatisation, allowing the attribution of all property rights to individuals (Smith 1981), and the second, nationalisation, involving an empowered regulator (primarily the state) to acquire and enforce all rights regarding the resource (Heilbroner 1974).

However, approaching the problem of governance binarily has attracted significant criticism on the grounds that both proposed solutions (privatization vs. nationalization) result in restricting the rights and actions of the actual users so as to destroy the social relationships and values which characterize a local community (i.e. the social capital), compromising both the long-term sustainability of the community and the effectiveness of the use of the resource. The best-known exponent of this perspective is Elinor Ostrom, the 2009 Nobel laureate in economics, who cites a series of empirical studies from across the world to show how communities are able to manage CPR for themselves, even without the existence of individual property rights (privatization) or an empowered regulatory authority (nationalization) (Ostrom 1990, 1992, 1999). This view raises the possibility of an alternative and more socially acceptable governance regime, the commons, enabling the end users to surmount the problems of collectiveaction to create strong and stable institutions capable of appropriating and managing their CPR in a sustainable manner. These institutions comprise specific social/informal arrangements (rules, norms, practices etc.), which define and allocate rights and obligations among the parties involved within an appropriate framework of legislation that involves mechanisms allowing for effective policing, enforcement and conflict resolution.

Furthermore, this literature (inter alia: Ostrom et al. 1999; Agrawal 2003; Arvanitidis et al. 2015) defines a series of factors shared by all successful collective governance regimes. These elements are categorized under five headings: the first of these concerns the resource itself; the second category delineates the particular characteristics of users: the third focuses on the nature of the relationship existing between the resource itself and its users; the fourth category is concerned with the specifics of the arrangements for governance and the institutional structures created to manage the CPR; and the last of the categories takes into account the external environment and the role of local and central authorities.

Put succinctly, the success of a collective governance regime is enhanced with the collective management of the resource by a clearly identifiable community involving interlinked stakeholders able to control the utilization of the CPR in compliance with local needs, preferences, practices and modes of collective action (formal and informal). The essence of this perspective is instrumental approaching the commons from an institutional or economic standpoint by concentrating on the internal nature and structures of governance regimes and emphasizing the primacy of practical issues in long-term CPR management and maintenance (Huron 2015). 


\subsection{The Governance of Public Open Space as a Commons}

'Public open space' connotes an all-embracing concept to encompass the various public spaces existing within the urban frame, that are, in general, open, freely accessible and available for use by the population for purposes of recreation, amenity and socialisation. Thus, POS can include such spaces as parks, sports fields, playgrounds, urban squares, plazas, the property of land trusts (school and church yards, vacant plots etc.), the normal roads, pavements, walkways, sidewalks and the whole slew of other public urban spaces. Access to POS is crucial for the well-being of the community by providing a variety of aesthetic, ecological, physical, psychological, and social benefits to residents (CABE space 2004).

POS constitutes a special category of CPR, since excluding the general population is not possible, (non-excludability), but use by some people can diminish the quantity or quality of space available to the rest (rivalry), including non-local visitors and tourists. This degradation of quality and/or quantity for others is a result of the 'saturated nature of cities'; the tendency to house ever larger numbers of people in relatively constricted areas of the urban fabric (Huron 2015). This engenders sufficient pressure on urban land use to force the residents into competing for the resource. Moreover, this situation is exacerbated by a lack of investment in providing and maintaining existing POS by local authorities (because of economic constraints, insufficient political will or administrative problems) thus leading to the deterioration and decline of these spaces. Avoidance of the impending 'tragedy' presaged by this decline necessitates the adoption of new and imaginative solutions for managing this developing situation. The option of a model of collective governance offers a solution.

To facilitate the collective governance of POS as a commons requires an institution of specific arrangements (rules, norms, mechanisms etc.) to control and regulate the use, appropriation and sustainable management of these spaces. To be effective, this would necessitate the joint evolution and development of such arrangements by the local community of users in conjunction with other stakeholders relying on these resources for their well-being. Qualifying for membership in these communities could be formally defined, or, perhaps more convivially, negotiated using ex post criteria, including residence or the agreement of the existing membership. The spectrum of interest groups involved in such a governance regime perform differing roles and have different rights (defined de jure or de facto) without these being either transferable or exclusive. Here, it is of crucial importance to underline that the practicalities of managing such resources is a critical element predicating the success of such governance regimes, with this more dependent on providing a framework for the allocation and enforcement of these diverse rights to the involved parties rather than on land ownership per se (Colding et al. 2013). The manner of structuring and implementing these rights has a crucial impact on the quality and quantity of the resulting benefits, and thus on the incentives to sustain the arrangements for the resource (Colding and Barthel 2013).

Our ability, as a community, for communication, becoming involved, entertaining ourselves, even for working have been, potentially at least, enormously enhanced over the last decade or so by innovations in ICT (McCullough 2007). The advent of wireless networks, smart devices, on line apps, services and cloud technology have provided 
previously undreamt-of facilities for becoming informed and acting and engaging with other people and space. The new possibilities for social interaction, networking, and collaboration, offering, at least in theory, the formation and function of new communities of shared interest. This constitutes something with major implications for new means of public participation and collective action (Sheller 2004; Hampton et al. 2010). In sum, such new ICT opportunities enable a whole new gamut of innovative means for the management of public spaces and the sustainability of collective governance. The following section is an attempt to chart these technologies and explore the potential of their relevance to the management of POS as a commons.

\section{Public Open Space, Humans and Information and Communication Technologies}

POS is not simply physical space (Carr et al. 1993); it is rather an assemblage, a synthesis, of space and narratives (stories) (DeLanda 2006). These narratives (Miles 2016) are mechanisms that enable indeterminate interactions between users (citizens) and resources (space). This scheme applies to complex urban environments where layers of human activity and the everyday life contribute to the experience of organically associated urban palimpsests. The affordances of this symbiosis, of plural narratives and spaces, contribute to the sustainable management of the city as a whole due to their impact on the social sustainability of the communities that inhabit the city.

Social sustainability and resilience can be explored through socio-ecological systems (SES) that offer a base to analyse interaction between humans and nature in different scales. Knowledge between social and environmental dynamics is essential for the development of SES (Cote and Nightingale 2011). Ongoing symbiosis between citizens and physical environment contributes narratives. Opportunities to utilize them in dynamic management is a vehicle to develop the cyberpark concept. Firstly, artful inquiries are used to recognize and communicate citizens' experiences and narratives associated to specific spaces, secondly this process offers the grounds for critical coreflection, through which key implications are identified and the initial conceptualization if ICT tools is constructed. This process is a driver to support citizens' agency in social sustainability contributing also to the ecological and economical sustainability of the space. Human adaptation to SES is continuously promoted by sharing knowledge and cultural exchange whilst the dialogue with POS management creates novel and resilient management (Suomalainen et al. 2017).

Arguably there is evidence of user segmentation of POS (Heritage Lottery Fund 2016), and in principle ICT add a new layer of interface - and therefore, ICT represent yet another mediation between space and its users - but this chapter argues for the conditions under which ICT can be used productively for enhancing a POS. These include mostly the parameters of a new way of asynchronous dialogue and information transmission that is performed not only between users, i.e., social aspects of spatial occupancy (Marušić 2010) but also between the POS and its users. Ward (2014) highlights that the "regulation of access and use of resources are of central concern to the maintenance and sustainability of the commons", suggesting that the latter involve conflict between individuals, social classes and communities. Collective uses of CPR 
are considered as an added value of a common 'stage' that hosts dialogue, communication and shared activities. In our case ICT render the access to the resources associated with a POS even more sensitive to regulation. This chapter though is occupied with this kind of POS that is characterised as open, inclusive, unplanned, of uncertain function, or lightly regulated (Sennett 2006). Williams et al. (2009) suggest that ICT can promote and facilitate these collective uses through digital media and platforms (such as wikis) that enable collective management and valuation of planning solutions. The chapter argues that in addition to interference between users of POS and physical access to its resources by means of promoting and managing activities that are typically highlighted by the conviviality of POS, such as leisure, sports, contemplation, meeting and co-presence, as well as open air museum, cinema, street theatre and other performances (Low et al. 2005), ICT could potentially contribute greatly to interpretation and inference of meanings through space occupancy. These data when managed openly, freely and creatively can facilitate engagement of users with the management of the resources of the space, and by doing so to add value to the POS towards its integration into a larger network of CPR (Taplin et al. 2002).

The appropriate use of ICT reintroduces physical space into the digital stage of the contemporary technologically-enabled social network of the cities (Graham 2005). This hybrid of spaces brings back to the cityscapes the micro- and nano-scales of relations that enable place-making and promote social interaction and belonging. Specifically, the framework of this approach involves the enabling of smart citizenship initiatives by means of:

- Citizen engagement in POS management through participatory design practices and ICT, since a sense of common purpose is induced typically by opportunities of or threats to change things (Schmelzkopf 1995) and this commoning is a meaningful performance of a POS;

- Citizen participation in urban monitoring and observation (congestion, noise, pollution);

- Exploitation of ICT and geo-referenced data for urban reactivation planning and policy making concerning important sites that have been neglected; cultural promotion and give prominence to less popular tourist destinations (Dodge and Kitchin 2007).

The above areas of contribution are empowered by the capacity of said tools and technological solutions to facilitate, and sometimes accelerate, the self-organisation of thematic communities that form groups around topics and sites of interest, and actively contribute relevant knowledge to the associated network. In this context the exploitation of ICT can disrupt typical considerations regarding accessibility of urban commons and equality of usage. As presented in Chapter 5.5, ICT integration can be expanded in order to reach larger audiences than the stakeholders of a POS, and enable even remote users to contribute knowledge. These crowdsourcing platforms can provide a stage for intercultural dialogue and informal contributions without the direct control/regulation of information exchange by intermediate stakeholders (Paulos et al. 2008).

Using the capacity of ICT tools in data transfer and communication of information of technologies such as GPS, RFID, Bluetooth, wireless beacons, surround sound, 
augmented reality and mixed reality, can enrich user experience of POS as urban commons, by means of interaction. This becomes possible by the likes of blogs, mobile apps for video and photo sharing, and other Web 2.0 applications (O'Reilly and Battelle 2009) that can enhance the degree of personalisation, openness and participation of users and citizens in the management of the POS (Rheingold 2001). Their engagement through activism, participation and smart citizenship is further facilitated not only by the operation of large-scale screens and projections in space that are open to everyone (Brignull and Rogers 2003) but mostly by developing virtual communities, which can be established by the technological interfaces above (Boyer 1996).

\section{Open-Ended Creative Practices of Accessing Public Data}

Digital technologies stage an interface that conditionally facilitates engagement between individuals and space (Calabrese 2009; Artopoulos 2012). This approach to technology as an interface between individuals (urban citizens) that are strangers (Jacobs 1961) and spaces that are occupied in habitual ways is based on the premise that rites and habits generate feelings of familiarity and in doing so contribute to the establishment of a sense of connection and belonging. Relevant discourse has been largely occupied for decades with the impact of ICT on both the erosion of social relationships and the capacity for intervention on inclusivity of POS, as well as on intensifying the disengagement of users that are already excluded (Barlas and Çalişkan 2006; Graham and Marvin 2001; Servon and Nelson 2001).

Nevertheless, there are many examples that showcase the contrary, with the recent cases of using social media for the communication of virtual communities of not only activists, but also of producers, sellers etc., and socially responsible practices such as carrotmob.org (2010), or the so-called 'civic hacking' (mySociety.org, 2010). Distinct from their exploitation as a tool for social segregation, there are opportunities for ICT to be used in a more inclusive way (Horelli and Kaaja 2002), and this chapter aspires to contribute to this end. This section suggests that the following steps of user engagement in co-management and co-creation (Figs. 1 and 2) could benefit from the use of ICT:

- Mapping of assets by means of spatially-distributed individual narratives, collective meanings and geo-location of stories;

- Visualisation of real-time (observation) data, and tools for user co-development of visualisation workflows that would be meaningful to them;

- Open-ended practices of data interpretation and enabling users to have meaningful access to real-time data.

These parameters and aspects of ICT are necessary for software and digital platforms to be explored as inclusive mechanisms for users to access POS in positive ways, e.g., in order to increase the openness of POS to variation and multiplicity (Stavrides 2016). This understanding of ICT-enabled POS builds on the use of a cybernetic electronic infrastructure (Batty 2013) that facilitates the engagement of the users in new idiomatic and localized conditions of urban commons (Artopoulos and Charalambous 2017). 'Devices' of engagement sourced from narrative-based cultural and creative industries, such as an 'exploration for learning' incentive, when integrated in 

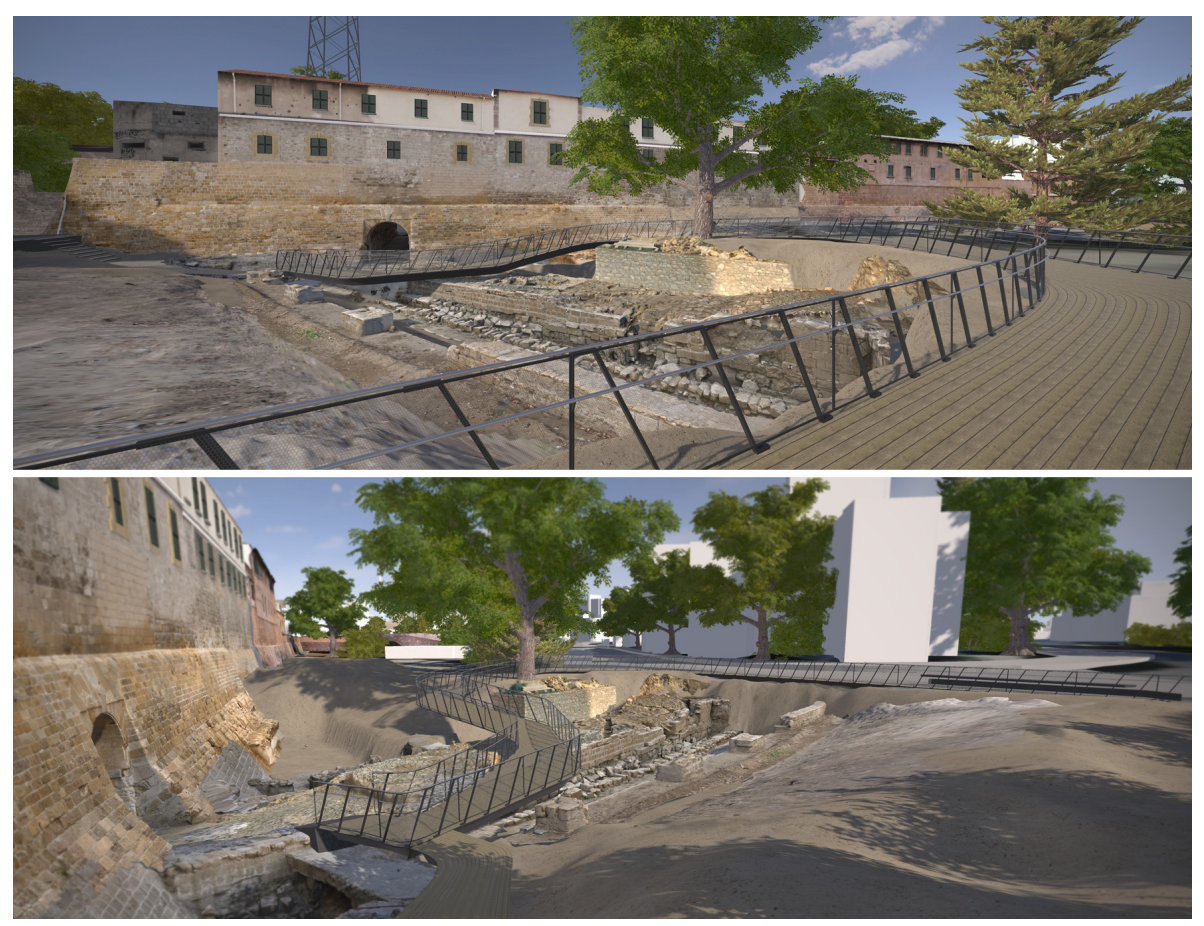

Fig. 1. The post-excavation management of the archaeological site of Paphos Gate in the historic core of the last divided capital of Europe, Nicosia, has been developed in line with the concept of cyberpark. It integrated spatially-distributed narratives and exposed users to interpretations of these data (as shown by Fig. 2). The research team devised a real-time interaction platform that aimed at the reintroduction of the archaeological site in the everyday life of the neighbourhood. Expected completion of construction works: February 2018 (C) Cyprus Institute; AVL, NSCA, University of Illinois at Urbana-Champaign; Cyprus Department of Antiquities; Municipality of Nicosia).

communication interfaces, can serve as a vehicle to empower users. In this approach visitors and citizens of the city, as well individuals and communities that may be excluded could be enabled to raise their voice and participate in the future development of the POS (Páez and Darren 2005). These technological solutions are built on conceptual devices for individuals' entanglement with space through goal-oriented activities, such as gamification (Atkinson and Willis 2009), playful engagement and serendipity (Wetzel et al. 2011).

Contextualised in societal challenges for the social resilience of urban space, these approaches differ from typical, corporate visions of smart cities. The former differs from the latter, as it interprets the user of ICT-networked information as a consumer. Current corporate visions of smart cities focus on data-consumption and the commodification of access to the big-data of the city (Schnitzer 2013), and value the citizens' well-being by the ease of access to such resources as public transport, infrastructure and digital media (Peugeot 2013). These visions of smart cities produce a 


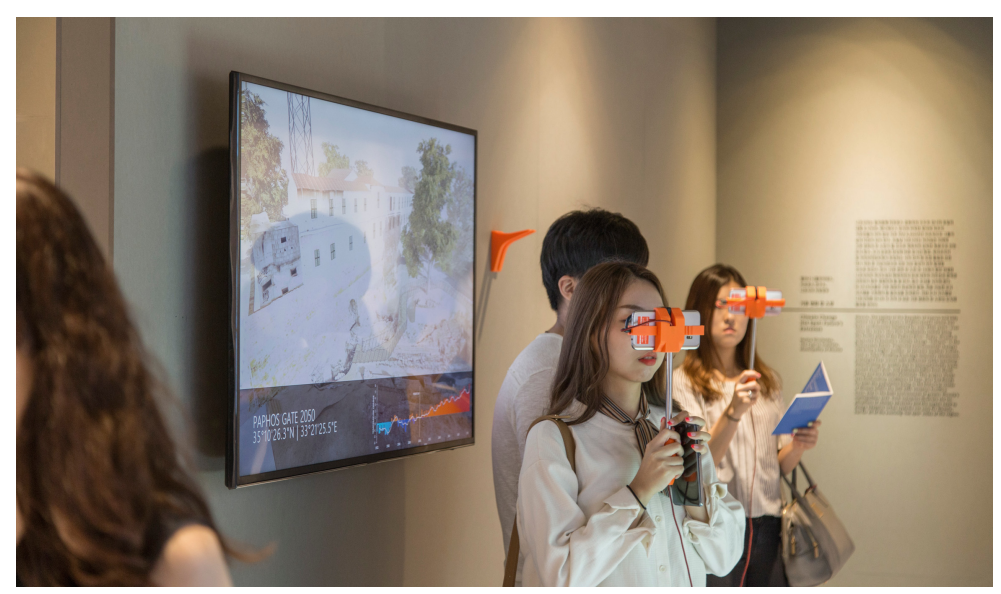

Fig. 2. Using mobile ICT is a low-budget solution of user engagement in meaningful interpretations of real-time data associated with a POS. Paphos Gate cyberpark was exhibited at the Seoul Biennale of Architecture and Urbanism 2017, titled "Imminent Commons", convened on the thematic of nine Commons in 50 cities.

false sense of accessibility to what is actually a representation of the city as a (cybernetic) machine, and the notion of acquiring a lightweight control over the city's noninterpretable complexity.

Alternatively, the approaches to ICT-augmented POS presented in the chapter are concerned with issues of equal opportunities in accessing 'other' types of urban commons (Bollier and Helfrich 2015), such as urban agriculture and community gardens, timebanks and telecommunications infrastructures (e.g., Guifi.net), which are self-regulated via collectives, fabrication labs and hackathons (Rodotá 2012). Annotating physical space with digital representations of ideas, feelings, thoughts, memories and informal narratives enables the observation, communication and visualisation of individual tolerance, contested realities and exchange of insights through space (i.e., resource) exploration.

In the context of this chapter, CPR are understood in a more open definition that is inclusive of interwoven networks of natural and social resources as well as of inhabitant's cultural production mechanisms (Patterson 2010), such as ecological zones and public spaces, air, water and infrastructure management systems, odours, and built heritage. The latter is here defined as anything that helps us collectively understand our present and speculate about our future conditions (http://www.heritageexchange.co.uk/, 2014). These opportunities for habitual interaction and familiar encounters are arguably limited in contemporary urban everyday life (Gilroy 2004). The ICT solutions presented are facing exactly this challenge as they aim to augment and multiply, in a pluralistic way, these opportunities for interaction across space and time, in the virtual projection of plural conditions and times (e.g., historical events) on the physical space of POS. 
Finally, another important aspect of the presented approach regards the capacity of said ICT tools in offering to citizens new opportunities for temporal personalisation of POS. This chapter suggests that the use of ICT on POS should allow for the interpretation of observation data by their users themselves, through the appropriate visualisation interfaces. The chapter argues that associating activities that are typically hosted by POS with individual narratives and meanings introduces additional values to a POS which increase civic participation and could potentially benefit the function of the larger network of POS in the city.

\section{Overview and Conclusions}

POS constitutes an urban commons that faces serious risk of decline (both in terms of quality and quantity), and even destruction (the so-called "tragedy of the commons"). This eventually leads to a degraded urban environment and a disadvantaged urban community. The conventional CPR literature prescribes as appropriate solutions to the problem either privatization or nationalization of the resource. However, many countries exhibit a number of characteristics (e.g., not clearly defined private property rights on specific resources, rigid and bureaucratic institutions with deficient policing and enforcement mechanisms, limited financial capability of local authorities, etc.), which preclude successful implementation of such governance structures. On the other hand, as Elinor Ostrom and other scholars have established, the stakeholders themselves can collectively develop institutional arrangements (more socially acceptable and with lower implementation costs), which enable them to ensure proper use and longevity of the common pool resource. The new mobile ICT, by enhancing human connectivity and enriching interaction, enable the reconfiguration of urban spatiality and of public spaces, and as a consequence allow for greater degree of creativity and freedom in the management, interpretation and valuation of the POS by its users through participation and engagement.

Contributing to this literature, the chapter has explored issues of data accessibility, data sharing, interoperability and mostly interpretation - and to this end data visualisation - that are now deemed prerequisites for the inclusive operation of ICT in POS, in order for the latter to be considered part of the network of CPR. Given that technological platforms and ICT are open to, and accessible by, all users, their exploitation through accessing content and exchanging information could expand the capacity of those areas in staging intercultural dialogue. This dynamic operation contextualises the use of ICT in a broader effort that attempts to bridge the gap between ecological and civic commons (Gidwani and Baviskar 2011). All these are aspects of interacting with a POS that can be valued for its conditionally positive impact to the space by tacitly promoting exchanges that grow new relations with the space and its users. In this context the chapter approached the hybrid of the POS and embedded ICT solutions as a seemingly indivisible new condition of urban commons in contemporary cities that is capable of contributing, under the right circumstances, to the resilience of the urban environment. 


\section{References}

Agrawal, A.: Sustainable governance of common-pool resources: context, methods, and politics. Ann. Rev. Anthropol. 32, 243-262 (2003)

Artopoulos, G.: Prototype spatial models of interaction. Int. J. Vis. Des. 6(3), 39-56 (2012)

Artopoulos, G., Charalambous, P.: Virtual environments as a technological interface between built heritage and the sustainable development of the city. Int. J. E-Plan. Res. (IJEPR) 8(1) (2019). ISSN: 2160-9918

Arvanitidis, P., Nasioka, F.: Urban open greenspace as a commons: an exploratory case study in Greece. Public Sect. 43(1), 19-32 (2017)

Arvanitidis, P., Nasioka, F., Dimogianni, S.: Water resource management in larisa: a 'tragedy of the commons?'. In: Filho, L.W., Sumer, V. (eds.) Sustainable Water Use and Management: Examples of New Approaches and Perspectives, pp. 65-89. Springer, Heidelberg (2015). https://doi.org/10.1007/978-3-319-12394-3_4

Atkinson, R., Willis, P.: Transparent cities: re-shaping the urban experience through interactive video game simulation. City 13(4), 403-417 (2009)

Barclay, P.: Trustworthiness and competitive altruism can also solve the "tragedy of the commons". Evol. Hum. Behav. 25, 209-220 (2004)

Barlas, A., Çalişkan, O.: Virtual space as a public sphere: rethinking the political and professional agenda of spatial planning and design. METU J. Fac. Archit. 23, 1-20 (2006)

Batty, M.: Big data, smart cities and city planning. Dialogues Hum. Geogr. 3(3), 274-279 (2013)

Bollier, D., Helfrich, S. (eds.): Patterns of Commoning. Commons Strategy Group, Amherst (2015)

Boyer, C.: CyberCities: Visual Perception in the Age of Electronic Communication. Princeton Architectural Press, New York (1996)

Brignull, H., Rogers, Y.: Enticing people to interact with large public displays in public spaces. In: Human-Computer Interaction INTERACT 2003: IFIP TC13 International Conference on Human-Computer Interaction, Zurich, Switzerland (2003)

CABE Space: The value of public space: how high quality parks and public spaces create economic, social and environmental value. CABE Space, London (2004)

Calabrese, F.: WikiCity: real-time location-sensitive tools for the city. In: Foth, M. (ed.) Handbook of Research on Urban Informatics: The Practice and Promise of the Real-Time City, pp. 390-413. Information Science Reference, Hershey (2009)

Carmona, M., De Magalhaes, C.: Public space management: present and potential. J. Environ. Plan. Manag. 49(1), 75-99 (2006)

Carr, S., Francis, M., Rivlin, L., Stone, A.M.: Public Space. Cambridge University Press, Cambridge (1993)

Colding, J., Barthel, S.: The potential of 'Urban Green Commons' in the resilience building of cities. Ecol. Econ. 86, 156-166 (2013)

Colding, J., Barthel, S., Bendt, P., Snep, R., van der Knaap, W., Ernstson, H.: Urban green commons: insights on urban common property systems. Glob. Environ. Change 23(5), 10391051 (2013)

DeLanda, M.: A New Philosophy of Society: Assemblage Theory and Social Complexity. Continuum, London (2006)

De Souza e Silva, A., Frith, J.: Mobile Interfaces in Public Spaces: Locational Privacy, Control, and Urban Sociability. Routledge, New York (2012)

Dodge, M., Kitchin, R.: 'Outlines of a world coming into existence': pervasive computing and the ethics of forgetting. Environ. Plan. B: Plan. Des. 34(3), 431-445 (2007) 
Ernstson, H., Sorlin, S., Elmqvist, T.: Social movements and ecosystem services - the role of social network structure in protecting and managing urban green areas in Stockholm. Ecol. Soc. 13(2), 39 (2008). http://www.ecologyandsociety.org/vol13/iss2/art39/

Fraser, E.D.G., Dougill, A.J., Mabee, W.E., Reed, M., McAlpine, P.: Bottom up and top down: analysis of participatory processes for sustainability indicator identification as a pathway to community empowerment and sustainable environmental management. J. Environ. Manag. 78 (2), 114-127 (2006)

Gidwani, V., Baviskar, A.: Urban commons review of urban affairs. Econ. Polit. Wkly, 66, 50, 10 December 2011. http://www.epw.in/journal/2011/50/review-urban-affairs-review-issues-specials/ urban-commons.html

Gilroy, P.: After Empire: Melancholia or Convivial Culture?. Routledge, London (2004)

Graham, S.: Software-sorted geographies. Prog. Hum. Geogr. 29(5), 1-19 (2005)

Graham, S., Marvin, S.: Splintering Urbanism: Networked Infrastructures, Technological Mobilities and the Urban Condition. Routledge, London (2001)

Hampton, K.N., Livio, O., Sessions Goulet, L.: The social life of wireless urban spaces: Internet use, social networks, and the public realm. J. Commun. 60(4), 701-722 (2010)

Hardin, G.: The tragedy of the commons. Science 162, 1243-1248 (1968)

Heilbroner, R.L.: An Inquiry into the Human Prospect. W.W. Norton, New York (1974)

Heritage Lottery Fund: State of the UK public parks II: Public survey. Report prepared by Britain Thinks. Heritage Lottery Fund, London (2016)

Horelli, L., Kaaja, M.: Opportunities and constraints of "internet assisted urban planning" with young people. J. Environ. Psychol. 22(1), 191-200 (2002)

Huron, A.: Working with strangers in saturated space: reclaiming and maintaining the urban commons. Antipode 47(4), 963-979 (2015)

Jacobs, J.: The Death and Life of Great American Cities. Random House, New York City (1961, 2002)

Lemonides, J.S., Young, A.L.: Provision of public open space in urban areas: determinants, obstacles, and incentives. J. Am. Inst. Plan. 44(3), 286-296 (1978)

Libecap, G.: The tragedy of the commons: property rights and markets as solutions to resource and environmental problems. Aust. J. Agric. Resour. Econ. 53(1), 129-144 (2009)

Low, S., Taplin, D., Scheld, S.: Rethinking Urban Parks, Public Space and Cultural Diversity. University of Texas Press, Austin (2005)

Marušić, B.: Analysis of patterns of spatial occupancy in urban open space using behaviour maps and GIS. Urban Des. Int. 16, 36-50 (2010)

McCullough, M.: New media urbanism: grounding ambient information technology. Environ. Plan. B: Plan. Des. 34, 383-395 (2007)

Miles, A.: Telling tales of participation: exploring the interplay of time and territory in cultural boundary work using participation narratives. Cult. Trends 5, 182-193 (2016)

Cote, M., Nightingale, A.J.: Resilience thinking meets social theory: situating social change in socio-ecological systems (SES) research. Prog. Hum. Geogr. 36(4), 475-489 (2011)

O'Reilly, T., Battelle, J.: What's next for web 2.0? In: Web Squared: Web 2.0 Five Years On (2009)

Ostrom, E.: Governing the commons: the evolution of institutions for collective action. Cambridge University Press, New York (1990)

Ostrom, E.: Community and the endogenous solution of commons problems. J. Theor. Polit. 4 (3), 343-351 (1992)

Ostrom, E.: Coping with tragedies of the commons. Ann. Rev. Polit. Sci. 2, 493-535 (1999)

Ostrom, E., Burger, J., Field, C., Norgaard, R., Policansky, D.: Revisiting the commons: local lessons, global challenges. Science 284, 278-282 (1999) 
Patterson, O.: The mechanisms of cultural reproduction: explaining the puzzle of persistence. In: Hall, J.R., Grindstaff, L., Lo, M.C. (eds.) Handbook of Cultural Sociology, pp. 139-151. Routledge, Abingdon (2010)

Paulos, E., Honicky, R., Hooker, B.: Citizen science: enabling participatory urbanism. In: Foth, M. (ed.) Handbook of Research on Urban Informatics: The Practice and Promise of the RealTime City, pp. 414-436. Information Science Reference, Hershey (2008)

Páez, A., Darren, M.S.: Spatial statistics for urban analysis: a review of techniques with examples. Geo J. 61(1), 53-67 (2005)

Peugeot, V.: Collaborative ou intelligente? La ville entre deux imaginaires. In: Carmes, M., Noyer, J.M. (eds.) Devenirs Urbains. Mines Paristech, Paris (2013)

Rheingold, H.: Rethinking virtual communities. In: Rheingold, H. (ed.) 2001 Edition of The Virtual Community, pp. 323-327. MIT Press, Cambridge (2001)

Rodotà, S.: Il valore dei beni communi, intervention Teatro Valle (2012). http://www. teatrovalleoccupato.it/il-valore-dei-beni-comuni-di-stefano-rodota. Accessed 6 Jan 2012

Sennett, R.: The open city. In: Urban Age. Cities Programme, London School of Economics and Political Science, London (2006)

Servon, L.J., Nelson, M.K.: Community technology centres: narrowing the digital divide in lowincome urban communities. J. Urban Aff. 23(3\&4), 279-290 (2001)

Schmelzkopf, K.: Urban community gardens as contested space. Geogr. Rev. 85(3), 364-381 (1995)

Schnitzer, M.: Herbert Reid, Betsy Taylor. Recovering the commons: democracy, place, and global Justice. Urbana and Chicago: University of Illinois Press 2010. Peace Change 38, 366368 (2013)

Sheller, M.: Mobile publics: beyond the network perspective. Environ. Plan. D 22(1), 39-52 (2004)

Shinew, K., Glover, T., Parry, D.: Leisure spaces as potential sites for interracial interaction: community gardens in urban areas. J. Leis. Res. 36(3), 336-355 (2004)

Smith, R.J.: Resolving the tragedy of the commons by creating private property rights in wildlife. Cato J. 1(2), 456-457 (1981)

Stavrides, S.: Common Space: The City as Commons. Zed Books, London (2016)

Suomalainen, S., Pässilä, A., Owens. A., Holtham, C.: Facilitating sustainable development through artful inquiries. In: 2nd Artem Organizational Creativity and Sustainability Conference Artem OCC 2017. Nancy School of art and design, ICN Business School and Mines Nancy (2017, forthcoming)

Taplin, D., Scheld, S., Low, S.: Rapid ethnographic assessment in urban parks: a case study of independence national historical park. Hum. Organ. 61(1), 80-93 (2002)

Ward, D.: The Commons in History: Culture, Conflict, and Ecology. The MIT Press, Cambridge (2014)

Wetzel, R., Blum, L., Feng, F., Oppermann, L., Straeubig, M.: Tidy city: a location-based game for city exploration based on user-created content. In: Mensch and Computer 2011: überMEDIEN|ÜBERmorgen. Universitätsverlag der TU Chemnitz, Munich (2011)

Williams, A., Robles, E., Dourish, P.: Urbane-ing the city: examining and refining the assumptions behind urban informatics. In: Foth, M. (ed.) Handbook of Research on Urban Informatics: The Practice and Promise of the Real-Time City, pp. 1-20. IGI Global, Hershey (2009) 
Open Access This chapter is licensed under the terms of the Creative Commons Attribution 4.0 International License (http://creativecommons.org/licenses/by/4.0/), which permits use, sharing, adaptation, distribution and reproduction in any medium or format, as long as you give appropriate credit to the original author(s) and the source, provide a link to the Creative Commons license and indicate if changes were made.

The images or other third party material in this chapter are included in the chapter's Creative Commons license, unless indicated otherwise in a credit line to the material. If material is not included in the chapter's Creative Commons license and your intended use is not permitted by statutory regulation or exceeds the permitted use, you will need to obtain permission directly from the copyright holder. 